\title{
Caregivers' burden and other selected problems of patients treated for heart failure
}

\section{Poczucie obciążenia i inne wybrane problemy dotyczące opiekunów chorych leczonych z powodu niewydolności serca}

\author{
Katarzyna Białek, Marcin Sadowski \\ Institute of Medical Sciences, Faculty of Medicine and Health Sciences, Jan Kochanowski University, Kielce, Poland \\ Head of the Institute: Prof. JKU Beata Kręcisz MD, PhD
}

Key words: heart failure, quality of life of caregivers, caregivers' burden.

Słowa kluczowe: niewydolność serca, jakość życia opiekunów pacjentów, poczucie obciążenia opiekunów.

\begin{abstract}
Heart failure is a rapidly growing health concern affecting nearly 800 thousand patients in Poland. Heart failure is the primary reason for hospitalisation after 65 years of age. And although most research focuses on the treatment and functioning of patients, life with heart failure is usually a shared experience and has a significant impact on the quality of life of other family members, and there are considerable implications for caregiver well-being. Research has shown that caregivers of patients with heart failure reported similar problems to the caregivers of patients with other chronic diseases; these included physical exhaustion, high stress, depressive and anxiety disorders, and reduced quality of life. The aim of this review is to summarise the needs and psychological reactions of caregivers of patients treated for heart failure, and an assessment of factors that affect the burden of caregivers and reduce their quality of life.
\end{abstract}

\section{Streszczenie}

Niewydolność serca to problem dotyczący prawie 800 tys. osób w Polsce. Jest także główną przyczyną hospitalizacji osób po 65. roku życia. Chociaż większość badań skupia się na leczeniu i funkcjonowaniu pacjentów, życie z niewydolnością serca jest zazwyczaj wspólnym doświadczeniem rodziny i choroba istotnie wpływa na jakość życia pozostałych jej członków. W badaniach wykazano, że opiekunowie pacjentów z niewydolnością serca doświadczają poczucia obciążenia i zgłaszają podobne problemy psychologiczne jak opiekunowie osób z innymi chorobami przewlekłymi, takimi jak przewlekła choroba płuc lub nowotwory. Najczęściej są to: wyczerpanie fizyczne, stres, lęk, depresja i obniżona jakość życia. Może to prowadzić do zjawiska wypalenia opiekuna. Celem artykułu jest podsumowanie potrzeb i reakcji psychologicznych opiekunów chorych leczonych z powodu niewydolności serca oraz ocena czynników, które wpływają na obciążenie opiekunów i obniżają ich jakość życia.

\section{Heart failure as a health and social problem}

Heart failure (HF) is a grave socio-economic problem in the world affecting about 10 million people in Europe and about 800 thousand in Poland. It is also the most common cause of hospitalisation after the age of 65 years and the cause of the deaths of 60,000 Poles a year [1-3]. Heart failure is most often caused by coronary heart disease, previous myocardial infarction, hypertension, heart valve defects, alcoholism, obesity, and diabetes [4-6]. Among patients hospitalised with HF the prevalence of diabetes mellitus is $42.6 \%$ and remains associated with increased frequency of death in this population [4].

Slowing down the aging process, improving the treatment of other diseases, and developing new techniques of interventional cardiology and electrotherapy to achieve haemodynamic improvement in cardiac patients are problems faced by contemporary medicine because of an ever-growing number of hospitalisations due to heart failure. The prognosis clearly indicates that in the next 10 years morbidity from HF will increase by $25 \%$, and it will be prevalent in all cardiovascular diseases $[2,6]$.

In the care of patients with heart failure, the efforts of doctors are focused not only on reducing the symptoms associated with HF and appropriate treatment of diseases leading to its progress, but also on reducing the risk of mortality and re-hospitalisations. The treatment of HF has improved over the years with the introduction of crucial forms of therapy, such as 
angiotensin-converting-enzyme inhibitors (ACE), $\beta$-adrenergic blockers, cardiac resynchronisation therapy (CRT), implantation of a cardioverter-defibrillator, orthotopic heart transplantation (OHT), and prevention of sudden cardiac death [7, 8]. One more alternative was noted - revascularisation in ischaemic $\mathrm{HF}$, but despite common use of both percutaneous coronary interventions (PCI) and coronary artery bypass grafting $(\mathrm{CABG})$ in ischaemic heart failure, data supporting its role are still deficient [7]. Nevertheless, studies still show a $30 \%$ rehospitalisation rate and a $10 \%$ death rate in the first 6 months after discharge [1].

In order to evaluate of the severity of HF in medical practice, two scales are used. The first of these is the New York Heart Association classification (NYHA). This fracture is based on the assessment of the severity of symptoms and physical efficiency, and it groups patients into four classes. To evaluate the progress of HF there are classifications used less often that have created according to the guidelines of the American scientific societies: the American College of Cardiology (ACC) and the American Heart Association (AHA) (stages A, $\mathrm{B}, \mathrm{C}$, and D). This classification is based on organic changes and damage to the myocardium [3]. However, it does not allow accurate grading of risk, especially in populations with advanced $\mathrm{HF}$, which prompted the development of the new prognostic scales that allow the evaluation of the patient's prognosis and estimation of the potential benefits of therapy and advanced methods of treatment. The available prognostic scales in everyday clinic practice include the Heart Failure Survival Score (HFSS), the Seattle Heart Failure Model (SHFM), and the Interagency Registry for Mechanically Assisted Circulatory Support (INTERMACS). The last one consists of seven clinical profiles, ranging from patients who have little chance of surviving (INTERMACS level 1) to patients who are clinically stable and do not have indications for urgent interventions [9]. In the diagnostic process of patients with congestive heart failure (CHF) serum B-type natriuretic peptide (BNP) is also important. What is more, $\mathrm{BNP}$ level has been reported to be strongly associated with $\mathrm{CHF}$, independently of other predictors [10].

In contrast to the trajectory in dementia or cancer, the course of HF is characterized by periods of stability interrupted by sharp exacerbations, which are often unpredictable, life threatening, and require immediate medical intervention, which translates into the quality of life of patients and their caregivers. It has been noted that compared to the functioning of healthy people and people with other chronic diseases such as hypertension, diabetes, atrial fibrillation or heart attack, digestive system diseases, lung diseases, kidney disease, or diabetes, the quality of life of patients with HF is definitely lower. The factors that affect its reduction in particular are physical suffering, cognitive-emotional disorders, awareness of the immediate threat to life, and re-hospitalisations [11].
Research has shown that higher levels of HF advancement, expressed with a higher N-terminal pro-B-type natriuretic peptide (NTpro-BNP), and higher NYHA class lead to the deterioration of the subjective QOL score of the patient, but to a small extent, especially in younger people. This may translate into the quality of cooperation with the carer, and thus the overall quality of care [12]. This is mainly due to reduced efficiency and physical fitness, which significantly limits most aspects of functioning, such as social relations, sexual activity, or the ability to work [13], and which is the cause of anxiety and depression [14]. Patients with $\mathrm{HF}$ are becoming more and more dependent on other people, as a result of which, due to the long-term negative impact on health and quality of life, inability to work, poor long-term prognosis [15], as well as the heavy burden on caregivers and their families, the HF is associated with enormous social costs [16].

\section{Family and the disease}

The disease in the family is not a purely individual problem of the sick person. It affects the family in its entirety. All symptoms appearing in a patient, to a greater or lesser extent, are 'shared' by the other members of the family system, often causing disorganisation of the daily and determined rhythm of life, thus burdening individuals with new tasks. Some of them may result from taking over the duties previously fulfilled by a sick person, others may be completely new, generated by the disease [17]. The family's behaviour is determined by the disease type, urgency, duration, and prognosis, which includes the degree of threat to life and possible disability of the patient. The premorbid system of the family, i.e. the depth of its integration and the ability to adapt in difficult situations, is also important [18]. However, the stress resulting from the new situation disturbs the balance of family functioning and may lead to its crisis.

The strength of the stressor, i.e. the disease depends on many circumstances, such as knowledge, the way doctors communicate and the circumstances accompanying this information, as well as general family health, not only the physical condition of its members, but also a wider context of factors [19]. Of course, the diagnosis may not always be a traumatic basis. However, when a patient goes to a ward in an emergency or life-threatening situation, this event is traumatic both for the patient and for the whole family [20].

Thus, the disease and hospitalisation of a close person is an extremely difficult situation. It is a biological and psychological stress requiring the compensation by various adaptive mechanisms [18]. At the very beginning, it brings uncertainty and fears concerning the diagnosis, course, and prognosis or, finally, treatment and contact with the medical environment [21]. What is more, hospitalisation is also a source of many negative emotions, such as: depression, lowered 
mood, anger, and sense of guilt. These are the result of strong anxiety resulting from the direct threat to the life of a close relative [22]. The experience of this unusual and difficult situation may trigger unexpected psychological changes.

Taking care of a patient is an important social issue. Patients' caregivers are an essential link in the health care system and a source of information about the course of the disease and the severity of its individual symptoms, and their correct actions can significantly improve the functioning of the patient. It is the caregivers who help the patient to perform daily activities, provide emotional support, and organise medical services and social assistance. Caregiving for the patient may, however, adversely affect the objective and subjective aspects of the caregiver's life - physical and mental health, work, social activity, interpersonal relations, and sex life [23].

The consequences of somatic illness and/or hospitalisation significantly change the current lifestyle of the family and caregivers. They limit the possibilities of normal, family, and professional life. At the same time, a need to undertake new activities related to the subordination to the health care system occurs. The disease also forces the learning of new, previously unknown care activities. It also causes resignation or modification of some life goals [24]. What is more, the treatment of a close person often interferes with or even prevents the satisfaction of one's own needs, such as the need for security, achievements, or autonomy [25]. Care for a sick person may also be related to the deprivation of interpersonal contacts, the loss of individuality, and the necessity to comply with a regulation that differs significantly from that of everyday life [24]. This fact also results in the tendency of carers to neglect themselves, their interests, needs, and health. Communication is also shallow. Family members avoid confrontation, parents often do not know how to talk to children about the dangers of the disease, and they - fearing that the parent may die are afraid to ask about anything. There is irritability and nervousness, crying, conflict, lack of strength and experiencing a disease that may limits concern for the patient [20]. What is more, greater burden and depletion negatively affect the quality of care and increase the probability of early institutionalisation [23].

In spite of great stress, family members often accept the situation and, consequently, take constructive action.

\section{The burden of caregivers of patients with heart failure}

Long-term care for patient results in consequences that function in psychology and medicine as the concept of "caregivers' burden". This phenomenon is defined as the experience of negative physical, psychological, emotional, social, and financial consequences as a result of dealing with a sick person [26]. The level of these consequences depends on various factors, i.e. the degree of patient independence, number of duties, level of specialist knowledge about the disease and its treatment, preparation for the role of a caregiver, and available sources of support [27]. The concept of burden is a complex term and is considered in objective terms, concerning the real deterioration of a given area of life and in subjective terms - as a mental and physical suffering constituting a secondary reaction to the existing situation and related restrictions [28].

The caregivers of HF patients are usually close relatives or friends of the patient, who provide help in everyday activities such as shopping, household financial management, reminding patients about taking medications, instrumental support, monitoring symptoms, following a low-sodium diet, planning and the pace of everyday life activities, assistance in making decisions regarding health care, as well as in taking emergency measures such as knowledge, when to call a doctor, involvement in social activities, providing security, emotional and spiritual support, and care at the end of life [14, 29].

Although caring for a patient is a satisfying experience, its burden can affect the health and well-being of caregivers in a negative way. When assessing the situation of care for patients with heart failure, it was noted that caregivers often do not have sufficient resources to meet the complex needs of patients. What is more, they report that they feel unprepared for the role of caregiver and are not adequately supported by the health care team [14]. Considering the amount of nursing tasks they perform, they also have less time to take care of their own health (inadequate sleep, forgetting to take medication, neglecting doctor's appointments) and often delay or sacrifice their own health needs to stay at home and take care of their loved ones. Studies have shown that the health condition worsened in over half of the HF patient caregivers. The most frequent ailments included: stress, prolonged fatigue, lack of energy, sleep problems, migraines, and depression. It is all the more worrying that the majority of those who care for are older people, who feel the consequences of physical exhaustion much faster [30-32]. The deterioration of their health was related in particular to variables such as advanced age of the patient, a greater number of comorbidities, and worse functioning of the patient [33].

The impairment of cognitive functions occurring in $25-50 \%$ of HF patients also significantly affects the caregivers [31]. In addition, progress in cardiac therapy, e.g. defibrillation and assistive devices, is another cause of greater stress due to the monitoring of the operation of these devices [34-36]. Many caregivers have also shown persistent anxiety, irritability, difficulty concentrating, and general confusion, which result in depressed mood. Symptoms of depression and anxiety experienced by caregivers may also induce 
psychosomatic deterioration, which in turn leads to increased morbidity in this population [26]. It was noted that people who reported higher levels of emotional tension as a result of care were $63 \%$ more likely to die than those who did not care for the patients [31].

Other factors related to symptoms of depression include lack of support from other family members, fear of an uncertain future, significantly reduced material status, readmissions, as well as duration of care $[37,38]$. However, what is interesting, those who have been looking after someone for less than 1 year showed a higher level of depressive symptoms and experienced greater burden than those with a longer care period. This may be related to the lack of knowledge and skills in patient care and frustration due to the loss of personal identity and unwillingness to accept oneself in the new role of a caregiver [29].

The caregivers of HF patients face a wide range of care challenges each day, forcing them to change their daily lives. As a result, they may have less time for friends and other family members. When assessing the impact of care on lifestyle, 33\% of caregivers reported a significant reduction in social activity, and as many as $74 \%$ said that patient care had led to changes in their own plans or complete planning avoidance [30]. This is consistent with the studies of Negarandeh et al., in which $53 \%$ of the caregivers of HF patients were reported to suffer from social isolation. Moreover, in comparison to the general population, they showed a lower assessment of life satisfaction, which may also be a risk factor for increased mortality [30, 39].

It seems that access to rehabilitation is also a significant problem. It has been reported that only one in 22 Polish patients with HF participate in cardiac rehabilitation programs. The inability to rehabilitate, especially patients in advanced HF periods, significantly translates into a reduction in the ability to return to work and reduces the quality of life of patients and their families, which can also significantly affect the sense of burden on caregivers. It is therefore important to introduce an active "disease management" system comprehensive care for patients with heart failure, which is a continuation of the currently implemented system of caring for patient after myocardial infarction and extension of the planned care system coordinated as part of basic health care [2]. The goal of cardiac rehabilitation is first of all restoring psychophysical fitness and facilitating the return to active life, and the effectiveness of their actions depends to a large extent on the involvement of the patient's family [40]. Studies have shown that rehabilitation of cardiac patients may reduce mortality from cardiac causes by $15-20 \%$ [41].

\section{The role of medical staff in the care of the family of patients with heart failure}

Considering how crucial the role of caregivers is, it is important to understand their needs and provide them with the attention they need. The better the well-being and quality of life of the caregiver, the better the care provided. What is more, the correct relation of the caregiver-patient strengthens the patient's sense of security, and relieves depression, anxiety, and loneliness. Good cooperation with the caregiver also results in a greater sense of control of health and a better frame of mind, which is associated with better results in the treatment of cardiovascular diseases [14].

Currently, the assessment of the quality of life conditioned by the state of health of patients and their caregivers (health-related quality of life - HRQoL) has been gaining increased significance. The HRQoL measurement is an extension of traditional, clinical health assessment based on physical examination, and it often informs patients and their caregivers about the course of the therapeutic process and the treatment used. Therefore, the members of therapeutic teams should be aware that the patient's caregiver is an inseparable element. It may not only improve the patient's self-care, but also facilitate communication with health care professionals and mediate in the aspect of negative consequences of care. It often occurs that the medical staff educating the family focuses on typical medical activities, avoiding the social and psychological aspects. Consultations and interventions should include discussions about the disease, its symptoms, and treatment options, as well as an analysis of the expectations and needs of patients and caregivers along with available formal support sources. Considering, however, that at some stage of the disease the family prepares for care at the end of life, such talks are all the more important and may raise additional concerns related to the issue of death [29]. From a psychological point of view, it enables a more objective presentation of the situation of the family and can contribute to the rationalisation of the reaction to the disease. It can reduce tension and stress and minimise the risk of depression. In this context, it is worth emphasising the importance of the doctor-patient relationship. The kind of information obtained from the doctor and the way of its transmission may affect the psychological wellbeing of the patient and the family and their attitude to the healing process. Therefore, the information provided by the medical staff should be clear and contain only relevant content adapted to the patient's education, age, and emotional state. In research on the expectations of families related to obtaining data about relatives in the intensive care unit, attention is paid to the clarity, comprehensibility, and completeness of information and its transfer in a partner-like manner. The literature states that only $50 \%$ of caregivers of intensive care unit (ICU) patients are satisfied with communication with doctors and understand the information about the diagnosis and treatment provided, which does not meet the basic standards of informed consent. The patients should also be aware that they are being treated in the most appropriate way, even if radical treatment is necessary, often causing high levels of anxiety [35]. 
In connection with the above, a significant part of the work of medical staff should include conversations with the patient and the family. Cooperation with health care workers positively affects the wellbeing of caregivers, and the knowledge about care and the availability of specialised support sources provides them with more effective disease monitoring, more efficient diagnosis of symptoms, and easier adaptation to the role of caregiver.

However, the analysis of the family situation is a real challenge because caregivers usually hide their reactions and emotions, taking care of the patient as their duty. Therefore, it is helpful to involve psychologists in the work of the ward. Depressive and anxiety symptoms in caregivers may have harmful physiological and psychological effects. Moreover, they can increase the susceptibility to infectious agents and alter the sympathetic nervous system and cardiovascular reactivity, while increasing the risk of cardiovascular disease in another family member [31]. Consultations with a psychologist may also provide knowledge about strategies for coping with stress and emotions in difficult situations.

Considering the above, it seems reasonable to name the caregivers of patients with HF as "hidden patients" [6]. Therefore, the role and support of the family by medical personnel is extremely important. This is important because the experiences of the patient's relatives are overlooked and underestimated in the process of caregiving. In the context of this situation, the key role in coordinating the carer-patient relationship is played by the nurse, who should use each contact with the patient and the family to build relationships and encourage cooperation. What is more, due to the nature of their work, family nurses have a great insight into the daily life of the patient and his or her relatives and can more accurately assess the care and nursing capacity of the family, which determines the overall care for the patient. Nursing interventions should include not only home visits, but also telemonitoring and ongoing individual conversations [33]. The quality and method of providing these benefits can undoubtedly affect the level of life satisfaction not only of caregivers, but also of patients [39]. The need to optimise health care resources in the aspect of financial support and as part of day care should also be emphasised [33].

\section{The burden of caregivers of patients with heart failure and other chronic diseases}

The struggle with the disease of a family member is a difficult life situation, with which some people deal better, others worse. Patients with HF usually require 24-hour care and support, as a result of which many caregivers experience physical and mental exhaustion, feel high stress, anxiety, depression, and other psychological problems. This is a difficult situation not only for the patient, but for the whole family.
However, the dissatisfaction with the current criteria for the assessment of treatment outcomes, as well as the economic aspects of health care as a whole, have resulted in a growing interest in quality of life research in recent years. They allow not only assessment of the impact of the disease but may also have a significant impact on the selection of optimal treatment methods and, along with clinical and functional assessment, be one of the most important determinants of the effectiveness of therapy [42].

The patients of cardiology departments were subjected to many studies to assess the quality of life, but generally they concerned selected groups of patients, e.g. patients after myocardial infarction $[43,44]$, patients with ischaemic heart disease [45], and patients after pacemaker or cardioverter-defibrillator implantation [46-48]. Unfortunately, much less attention is paid to the caregivers of cardiac patients. What is more, there are no Polish studies dealing with the subject of cardiac patients' caregivers, and the empirical verifications conducted so far most often concerned the caregivers of Alzheimer's disease [49], Parkinson's disease [28], multiple sclerosis [50], cancer [51], or mechanically ventilated patients [52]. Meanwhile, research in international centres has clearly demonstrated that caregivers of patients with HF reported similar problems to the caregivers of patients with other chronic diseases, such as cancer and chronic obstructive pulmonary disease [53], which largely affects the health and well-being of caregivers and significantly reduces their quality of life, changing it in a negative way. However, some differences in the context of HF may present unique challenges. Frequent periods of exacerbation leading to hospitalisation and the need to monitor signs and symptoms to prevent decompensation are extremely burdensome [31]. According to clinical registers, approximately $1 / 4$ of people with acute $\mathrm{HF}$ are re-hospitalised within three months of discharge from the hospital. This is important because the HF hospitalisation rate in Poland is alarmingly high and equals $6 / 1000$ inhabitants, and $83 \%$ of all hospital admissions related to HF are sudden cases [2].

Shortness of breath may be particularly distressing, as well. In the early stages of HF shortness of breath occurs only with great effort, but in the progressive stages of the disease, it appears even with ordinary activities such as using the toilet, moving around the house, or washing the dishes, so many caregivers reported the need for support in the field of practical skills related to the care and rehabilitation of the patient and tips on how to proceed in emergency situations. Studies have shown that caregivers who received such information showed lower levels of anxiety, depression, and anger, and a greater sense of security $[39,54]$. Many fears concerned the administration of medicines to the patient, especially directly after discharge of the patient from the hospital and those used in the treatment of comorbidities [29]. 
However, no references were found on the impact of the severity of HF on the burden of caregivers. However, taking into account various factors, such as the level of symptoms, the degree of acceptance of the disease, coping with stress, or individual personality traits, this problem seems to be extremely important and should be submitted for analysis.

\section{Conclusions}

According to the literature, caregivers of patients treated for HF experience many negative emotions, such as anxiety, depression, fear, and a sense of burden. The quality of care provided by a caregiver decreases if the resources and knowledge related to patient care are not available to them. These issues not only contribute to the burden and stress of caregivers, but also worsen the condition of patients. The lack of social support may lead to a "burnout" of the caregiver, which results in discouragement and reduced quality of care. In the United States, there are even discussions about the inclusion of psychotherapy for HF patients and their families. Studies have shown that a short session with elements of cognitive behavioural therapy conducted by nurses in a group of patients with NS with symptoms of depression and anxiety has a positive effect on the quality of life of patients and their families [11]. Comprehensive treatment and care of patients with HF is a challenge and requires the patient, health care professionals, and caregivers to coordinate their efforts as a team. This will allow new therapeutic goals to be set, will improve the quality of services provided, and will adapt the therapy to the individual needs of patients and create adequate support systems, which will improve the quality of life not only of the patients but also of their caregivers.

\section{Conflict of interest}

The authors declare no conflict of interest.

\section{References}

1. Praska-Ogińska A, Bednarski J. Leczenie ostrej niewydolności serca. Folia Cardiol 2017; 12: 306-316.

2. Nessler J, Nessler B. Pacjent z zaostrzeniem niewydolności serca - praktyczne wskazówki postępowania w okresie okołowypisowym. Choroby Serca Naczyń 2016; 13: 69-78.

3. Kowalczyk B, Czyż R, Kaźmierska B. Niewydolność serca - definicja, klasyfikacja, epidemiologia, objawy i leczenie. J Educ Health Sport 2016; 6: 352-367.

4. Siedlecki Ł, Szyguła-Jurkiewicz B, Pyka Ł, Król B, Szczurek W. Clinical features, management and mortality in diabetic and non-diabetic patients with heart failure observations from the COMMIT-HF registry. Kardiochir Torakochirur Pol 2017; 14: 170-174.

5. Król B, Oprzędkiewicz A, Szczurek W, Szyguła-Jurkiewicz B. Obesity in patients with end-stage heart failure. Kardiochir Torakochir Pol 2018; 15: 176-179.
6. Gusdal AK, Josefsson K, Thors Adolfsson E, Martin L. Registered nurses' perceptions about the situation of family caregivers to patients with heart failure - A Focus Group Interview Study. PLoS One 2016; 11: e0160302.

7. Pyka $€$, Hawranek M, Gąsior M. Revascularization in ischemic heart failure with reduced left ventricular ejection fraction. The impact of complete revascularization. Kardiochir Torakochir Pol 2017; 14: 37-42.

8. Chen A, Chen X, Shen Y, Li W. Modalities of ventricular pacing for cardiac resynchronization therapy in patients with heart failure: a meta-analysis and systematic review. Arch Med Sci 2017; 13: 1006-1017.

9. Szczurek W, Szyguła-Jurkiewicz B, Siedlecki Ł, Gąsior M. Prognostic scales in advanced heart failure. Kardiochir Torakochir Pol 2018; 15: 183-187.

10. Kadri AN, Kaw R, Al-Khadra Y, Abuamsha H, Ravakhah K, Hernandez AV, Tang W. The role of B-type natriuretic peptide in diagnosing acute decompensated heart failure in chronic kidney disease patients. Arch Med Sci 2018; 14: 1003-1009.

11. Mościcka S, Wójcik D, Mamcarz A. Jakość życia pacjentów z niewydolnością serca. Forum Med Rodzinnej 2015; 9: 435-442.

12. Fedyk-Łukasik M, Krzanowska K, Grodzicki T. Przewlekła niewydolność serca i przewlekła obturacyjna choroba płuc - problem schorzeń współistniejących. Choroby Serca Naczyń 2008; 5: 68-75.

13. Klocek M, Czarnecka D. Jakość życia kobiet z przewlekłą niewydolnością serca. Przegl Lek 2016; 73: 435-438.

14. Evangelista LS, Strömberg A, Dionne-Odom JN. An integrated review of interventions to improve psychological outcomes in caregivers of patients with heart failure. Curr Opin Support Palliat Care 2016; 10: 24-31.

15. Ponikowski P, Voors AA, Anker SD, Bueno H, Cleland JG, Coats AJ, Falk V, González-Juanatey JR, Harjola VP, Jankowska EA, Jessup M, Linde C, Nihoyannopoulos P, Parissis JT, Pieske B, Riley JP, Rosano GM, Ruilope LM, Ruschitzka F, Rutten FH, van der Meer P. Wytyczne ESC dotyczące diagnostyki i leczenia ostrej i przewlekłej niewydolności serca w 2016 roku. Kardiol Pol 2016; 74: 1037-1147.

16. Humphrey L, Kulich K, Deschaseaux C, Blackburn S, Maquire L, Strömberg A. The Caregiver Burden Questionnaire for Heart Failure (CBQ-HF): face and content validity. Health Quality o Life Outcomes 2013; 11: 84.

17. Białek K. Rodzina pod wpływem choroby jako stresora. Państwo i Społeczeństwo 2015; 4: 79-88.

18. Motyka M, Załuski M. Choroba jako kryzys a zmiany rozwojowe podczas choroby. Pielęgn XXI Wieku 2010; 3-4: 32-33.

19. Cyranka K. Psychologiczne aspekty funkcjonowania rodziny dziecka chorego na cukrzycę typu I. Psychoterapia 2012; 1: 51-63.

20. Deręgowska J. Rodzina w zmaganiach z chorobą nowotworową dziecka. Szansa rozwoju czy ryzyko zaburzeń. Piel Pol 2013; 3: 197-205.

21. Białek K, Lickiewicz J. Ryzyko wystąpienia zespołu stresu pourazowego u członków rodzin pacjentów leczonych na Oddziale Intensywnej Terapii. Anestezjol Ratown 2015; 9: 392-398.

22. Foss KR, Tenholder MF. Expectations and needs of persons with family members in an intensive care unit as opposed to a general ward. South Med J 1993; 86: 380-384. 
23. Rachel W, Jabłoński M, Datka W, Zięba A. Jakość życia opiekunów pacjentów z otępieniem w chorobie Alzheimera. Psychoger Pol 2014; 11: 67-78.

24. Kowalczyk M. Miłość i gniew. Koszty emocjonalne rodzin w kontekście opieki nad bliskim chorym. Med Paliat Prakt 2012; 6: 23-27.

25. Leksowka A, Jaworowska I, Gorczyca P. Choroba somatyczna jako wyzwanie adaptacyjne człowieka. Folia Cardiol Excerpta 2011; 6: 244-248.

26. Al-Rawashdeh SY, Lennie TA, Chung ML. Psychometrics of the zarit burden interview in caregivers of patients with heart failure. J Cardiovasc Nurs 2016; 31: E21-E28.

27. Bahrami M, Etemadifar S, Shahriari M, Khosravi-Farsani A. Caregiver burden among Iranian heart failure family caregivers: a descriptive, exploratory, qualitative study. Iran J Nurs Midwifery Res 2014; 19: 56-63.

28. Golińska P, Bidzan M. Poczucie obciążenia opiekunów osób z chorobą Parkinsona. Przegląd badań. Geriatria 2017; 11: 22-28.

29. Wingham J, Frost J, Britten N, Jolly K, Greaves C, Abraham C, Delal H. Needs of caregivers in heart failure management: a qualitative study. Chronic Illness 2015; 11: 304-319.

30. Jackson J, Cotton SE, Wirta BC, Proence CC, Zhang M, Lahoz R, Calado FJ. Burden of heart failure on caregivers in China: results from a cross-sectional survey. Drug Des Devel Ther 2018; 12: 1669-1678.

31. Pressler J, Gradus-Pizlo I, Chubinski SD, Smith G, Wheeler S, Wu J, Sloan R. Family caregiver outcomes in heart failure. Am J Crit Care 2009; 18: 149-159.

32. Luttik ML, Jaarsma T, Veeger N, Tijseen J, Sanderman R, van Veldhuisen DJ. Caregiver burden in partners of heart failure patients: limited influence of disease severity. Eur J Heart Fail 2007; 9: 695-701.

33. Agren S, Strömberg A, Jaarsma T, Luttik MA. Caregiving tasks and caregiven burden: effects of an psycho-educational intervention in partners of patients with post-operative heart failure. Heart Lung 2015; 44: 270-275.

34. Nimmon L, Bates J, Kimel G, Lingard L. Patients with heart failure and their partners with chronic illness: interdependence in multiple dimensions of time. J Multidiscip Healthc 2018; 11: 175-186.

35. Jones C, Backman C, Griffiths RD. Intensive care diaries and relatives symptoms of posttraumatic stress disorder after critical illness: a pilot study. Am J Crit Care 2012; 21: 172-176.

36. Hu X, Huang W, Su Y, Qu M, Peng X. Depressive symptoms in Chinese family caregivers of patients with heart failure. A cross-sectional study. Medicine 2017; 96: e6480.

37. Dunbar SB, Clark PC, Quinn C, Gary RA, Kaslo WN. Family influences on heart failure self-care and outcomes. Cardiovasc Nurs 2008; 23: 258-265.

38. Hu X, Dolansky MA, Su Y, Hu X, Qu M, Zhou L. Effect of a multidisciplinary supportive program for family caregivers of patients with heart failure on caregiver burden, quality of life, and depression: a randomized controlled study. Int J Nurs Stud 2016; 62: 11-21.

39. Negarandeh R, Delkhosh M, Janani L, Samiei N, Ghasemi E. The relationship between perceived life changes and mental health in family caregivers of patients with heart failure who referred to Rajaei Cardiovascular Medical and Research Center, Tehran. Int J Commun Based Nurs Midwifery 2015; 3: 283-291.
40. Dąbrowska J, Jurek A, Krakowska A, Grąbczewska Z, Kubica A. Udział rodziny chorego w rehabilitacji osób po zawale serca. Cardiovasc Forum 2007; 12: 18-22.

41. Piotrowicz R. POLKARD 2005-2008. Kardiol Pol 2008; 66: 1357-1358.

42. Kurpas D, Bąk E, Seń M, Wróblewska I, Mroczek B. Jakość życia pacjentów oddziału kardiologii inwazyjnej. Fam Med Prim Care Rev 2014; 16: 120-123.

43. Celiński R. Wpływ leczenia inwazyjnego lub zachowawczego na jakość chorych z rozpoznanymi ostrymi zespołami wieńcowymi. Pol Merkur Lekarski 2008; 25: 148-320.

44. Juźwiszyn J, Mazurek W, Wojewoda B, Jańczak D, Grzebieniak T. Wybrane aspekty jakości życia chorych na niedokrwienną chorobę serca poddanych planowej przezskórnej plastyce naczyń wieńcowych. Piel Zdr Pub 2012; 2: 7-13.

45. Klocek M, Kawecka-Jaszcz K. Jakość życia osób z chorobą niedokrwienną serca. In: Jakość życia w chorobach układu sercowo-naczyniowego. Metody pomiaru i znaczenie kliniczne. Kawecka-Jaszcz K, Klocek M, Tobiasz-Adamczyk B (eds). Termedia, Poznań 2006.

46. Małecka B, Ząbek A, Lelakowski J, Małecki J. Zmiana jakości życia oraz klasyfikacji NYHA u chorych z zaawansowaną niewydolnością serca i utrwalonym migotaniem przedsionków po 12 miesiącach od rozbudowy systemu stymulacji. Pol Merkur Lekarski 2012; 32: 9-13.

47. Reczek A, Stańczykiewicz-Kudła K, Brzostek T, Malinowska-Lipień I, Kawalec E. Jakość życia chorych po wszczepieniu stymulatora serca. Piel Chir Angiol 2012; 2: 107-113.

48. Orzechowski P, Wąsowski M. Leczenie przewlekłej niewydolności serca. Post Nauk Med 2009; 12: 329-333.

49. Mazurkiewicz A, Sidor K, Podstawka D, Wolak B, Makara-Studzińska M. Wpływ wsparcia na jakość życia osób sprawujących opiekę nad chorymi na Alzheimera. Med Paliat 2015; 7: 250-255.

50. Kędra E, Borczykowska-Rzepka M, Wilusz J. Ocena jakości życia rodzin/opiekunów osób chorych na stwardnienie rozsiane dokonana w świetle przeprowadzonych badań. Piel Pol 2017; 3: 396-403.

51. Gawlik M, Kurpas D. Ocena jakości życia opiekunów domowych pacjentów z chorobą nowotworową z wykorzystaniem kwestionariusza Caregiver Quality of Life-Cancer. Med Paliat 2015; 7: 67-77.

52. Stodulska M, Biłogan L. Wybrane aspekty jakości życia chorych wentylowanych mechanicznie w warunkach domowych oraz ich opiekunów. Piel Anestozjol Intens Opiece 2016; 2: 33-40.

53. Burton AM, Sautter JM, Tulsky JA, Lindquist JH, Hays JC, Olsen MK. Burden and well-being among a diverse sample of cancer, congestive heart failure, and chronic obstructive pulmonary disease caregivers. J Pain Symptom Manage 2012; 44: 410-420.

54. Bidwell JT, Lyons KS, Lee CS, Caregiver well-being and patient outcomes in heart failure: a meta-analysis. J Cardiovasc Nurs 2017; 32: 372-382.

\section{Address for correspondence:}

\section{Katarzyna Białek}

Institute of Medical Sciences

Faculty of Medicine and Health Sciences

Jan Kochanowski University

al. IX Wieków Kielc 19, 25-317 Kielce, Poland

Phone: +48512318 732

E-mail: katarzynabialek@vp.pl 